\title{
EKONOMI KREATIF: TALENTA BARU PEMICU DAYA SAING DAERAH
}

\author{
CREATIVE ECONOMY: NEW TALENTS FOR \\ REGIONAL COMPETITIVENESS TRIGGERS
}

\author{
Herie Saksono \\ Pusat Penelitian dan Pengembangan Pemerintahan Umum dan Kependudukan \\ Badan Penelitian dan Pengembangan (BPP) - Kementerian Dalam Negeri \\ Jl. Kramat Raya No. 132 - Senen, Jakarta \\ Nomor Telp./Faks:+62 21314 0454; e-mail: herie.saksono@yahoo.com \\ Diterima: 27 April 2012, Direvisi: 3 Mei 2012, Disetujui: 31 Mei 2012
}

\begin{abstract}
Abstrak
Studi ini bertujuan untuk lebih memahami keberadaan ekonomi kreatif sebagai talenta baru yang diprediksi mampu memicu daya saing daerah. Hingga saat ini, pengangguran, kemiskinan, dan pertumbuhan ekonomi masih menjadi persoalan klasik yang memerlukan solusi. Studi ini menggunakan pendekatan deskriptif-kualitatif dengan metode studi literatur. Hasil analisis menyatakan bahwa ekonomi kreatif merupakan ide/gagasan yang diharapkan memberi nilai tambah ekonomi. Ekonomi kreatif merupakan alternatif solusi permasalahan perekonomian. Namun, dalam penyelenggaraannya seringkali menemui kendala. Direkomendasikan kepada Pemerintah maupun pemerintahan daerah agar segera membangun komitmen, membenahi regulasi, dan mengaktualisasikan ekonomi kreatif, sehingga keberadaan ekonomi kreatif dapat menstimulasi pertumbuhan ekonomi dan meningkatkan daya saing daerah dan bahkan nasional.
\end{abstract}

Kata Kunci: ekonomi kreatif, talenta baru, dan daya saing daerah.

\begin{abstract}
This study aims to understanding the presence of creative economy as a new talent that predicted as a trigger for regional competitiveness. Until now, unemployment, poverty, and economic growth became a classic problem that requires solutions. This study use descriptive-qualitative approach with literature study method. The analysis results stated that creative economy is an idea that hopefully adding the economic value. Creative economy is an alternative solution for the economic problems. However, the implementation is constantly facing obstacles. It is highly recommended that central and local government must immediately build a commitment to improve regulations and to actualized creative economy so that the presence of creative economy can stimulate economic growth and enhance regional and even national competitiveness.
\end{abstract}

Keywords: creative economy, new talent, and regional competitiveness

\section{PENDAHULUAN}

Masyarakat mulai akrab dengan industri rumahan (home industry) yang menjual ide kreatif untuk menghasilkan pendapatan. Para pakar ekonomi menyebutnya dengan istilah "ekonomi kreatif", yakni sebuah "talenta" (baru) yang mengubah kehidupan masyarakat melalui ide/gagasan kreatif, sehingga menghasilkan produk-produk bernilai tambah ekonomi yang mampu menjadikan kehidupan lebih sejahtera. Kata "talenta" sendiri memiliki banyak definisi atau pengertian. Menurut Webster's New World Dictionary (1991: 1365), talent - dalam bahasa Inggris kuno (Old English): talente, dalam bahasa Latin: talentum, dan dalam bahasa Yunani: talanton. Merupakan kata benda yang diartikan sebagai: 1 any of various large units of weight or of money (the value of a talent weight in gold, silver, etc.) used in ancient Greece, Rome, the Middle East, etc. 2 any natural ability or power; natural endowment 3 a superior, apparently natural ability in the arts or sciences or in the learning or doing of anything 4 people cellectively, or a person, with talent [to encourage young talent]. Menurut Kamus Besar Bahasa Indonesia atau KBBI (2005: 1127) dinyatakan bahwa talenta adalah pembawaan seseorang sejak lahir; bakat. Menyimak beragam pengertian dan definisi tersebut, dalam konteks ini "talenta" diartikan sebagai anugerah Tuhan berupa ide/gagasan kreatif yang bernilai tambah ekonomi dan karenanya dapat mengubah kehidupan menjadi lebih sejahtera.

Bagaimana dengan ekonomi kreatif? Ekonomi kreatif dimulai ketika pada tahun 1995 di London, Landry dan Bianchini merilis ide kreatif mereka dalam buku The Creative City. Di era Y2K (Year 2 Kilo) atau tahun 2000, Landry kembali mengemukakan ide yang menggugah para kepala daerah (walikota) dan pemangku kepentingan pembangunan ekonomi-budaya melalui bukunya, The Creative City: A Toolkit for Urban Innovators. Sekali lagi, konsep yang ditawarkan adalah "Kota Kreatif" (creative city). Diawal risetnya, Florida (2012) menyampaikan hasil studi tentang 
transformasi produk-produk perekonomian, industri kreatif, dan bangkitnya kelas kreatif (The Rise of Creative Class). Dinyatakan pula bahwa perekonomian dunia telah mengalami pergeseran. Bila pada abad XX, ekonomi bertumpu pada produk manufaktur, maka saat ini telah mengalami pergeseran ke ekonomi yang bersumber dari kreativitas sebagai komoditas utamanya di abad XXI.

Di sisi lain, memasuki milenium kedua, Pemerintah Indonesia menetapkan Undang-Undang Nomor 22 Tahun 1999 tentang Pemerintahan Daerah yang merupakan penanda dimulainya era desentralisasi (baca: otonomi daerah). Otonomi daerah bertujuan mewujudkan tata kelola kepemerintahan yang baik (good governance), penyediaan pelayanan publik, dan peningkatan daya saing daerah menuju masyarakat sejahtera. Desentralisasi telah merubah wajah teritorial pemerintahan dan lahirnya beberapa daerah otonom. Saat ini, wilayah administrasi pemerintahan di Indonesia terdiri atas 33 provinsi, 398 kabupaten, 93 kota, 5 kotamadya, dan 1 kabupaten administrasi.

Mengapa ekonomi kreatif? Haruskah daerah otonom menjadi sebuah "kota kreatif"? Sampai saat ini, Indonesia masih menghadapi berbagai pernasalahan terkait dengan kesejahteraan masyarakatnya. Dalam perspektif sosio-ekonomi terlihat bahwa sekalipun terjadi pertumbuhan ekonomi dalam negeri, namun beberapa indikator pembangunan belum menunjukkan perubahan yang signifikan dan memuaskan. Permasalahan ini merupakan akumulasi berbagai persoalan di daerah. Bahkan tren selama 3 (tiga) tahun terakhir (20092011) mengindikasikan secara jelas dan nyata beberapa indikator yang harus segera direspons dengan seksama melalui talenta baru dan strategi yang tepat (lihat Tabel 1).

Memerhatikan arah perkembangan (trend) jumlah penduduk Indonesia, tingginya angka pengangguran terbuka (APT), jumlah penduduk miskin, pertumbuhan ekonomi, dan produk domestik bruto (PDB) atas dasar harga konstan (ADHK) tahun 2000, sesungguhnya justru terdapat peluang untuk mengeliminasi pengangguran terbuka dan mereduksi kemiskinan yang pada saatnya meningkatkan kesejahteraan masyarakat. Hal ini dapat dilakukan dengan talenta baru - ekonomi kreatif.
Ekonomi kreatif merupakan sistem transaksi (supply and demand) yang memiliki pengertian lebih luas daripada industri kreatif. Menurut Wikipedia, industri kreatif adalah a set of interlocking industry sectors that focus on creating unique property, content or design that previously did not exist. Sedangkan Department for Culture, Media and Sport-DCMS pemerintah United Kingdom (UK) memberikan definisi tentang industri kreatif sebagai as those industries which their origin in individual creativity, skill and talent, and which have a potential for wealth and job creation through the generation and exploration of intellectual property and content (industri yang berasal dari pemanfaatan kreativitas, ketrampilan serta bakat individu untuk menciptakan kesejahteraan serta lapangan pekerjaan melalui penciptaan dan pemanfaatan daya kreasi dan daya cipta individu tersebut). (Creative Industries Mapping Document, DCMS, 2001).

Para pihak yang berkecimpung dalam industri kreatif banyak mengacu pada definsi dari UK DCMS. Departemen Perdagangan Republik Indonesia ketika melakukan studi pemetaan industri kreatif (2007) juga menggunakan acuan definisi industri kreatif yang sama dengan UK DCMS. Pemerintah UK mengejawantahkan industri kreatif menjadi 11 subsektor, sedangkan pemerintah RI menetapkan 14 subsektor yang merupakan industri berbasis kreativitas. Berikut ini pembagian subsektor industri kreatif menurut beberapa versi.

Subsektor-subsektor yang dimasukkan dalam fokus industri kreatif pada dasarnya diserahkan pada kebijakan negara yang bersangkutan. Karena, tiap negara yang concern terhadap industri kreatif membangun kompetensi ekonomi kreatif dengan caranya masing-masing sesuai dengan kemampuan yang dimiliki oleh negara tersebut. Hal yang perlu dijadikan catatan adalah subsektor-subsektor kompetensi dalam industri kreatif tersebut pada dasarnya dibangun melalui pengembangan tiga fokus industri berbasis, yaitu: (1) lapangan usaha kreatif dan budaya (creative cultural industry), (2) lapangan usaha kreatif (creative industry), dan (3) hak kekayaan intelektual (copyright industry).

Maknanya, menjadi perhatian kita bahwa ketika Pemerintah telah menetapkan 14 sub sektor industri kreatif, maka diperlukan langkah-langkah

Tabel 1. Peluang Ekonomi Kreatif Sesuai Realita Sosial-Ekonomi Dalam Negeri

\begin{tabular}{rlrrr}
\hline No. & \multicolumn{3}{c}{ Kondisi Saat Ini } & \multicolumn{3}{c}{ Tahun } \\
\cline { 3 - 5 } & & 2009 & \multicolumn{1}{c}{2010} \\
\hline 1. & Jumlah Penduduk (Juta Jiwa) & 231,369 & 237,641 & 241.453 \\
2. & Jumlah Pengangguran Terbuka (Ribu Jiwa) & $8.962,617$ & $8.319,779$ & $7.700,086$ \\
3. & Penduduk Miskin (Ribu Jiwa) & $32.530,00$ & $31.023,40$ & $30.018,93$ \\
4. & Persentase Penduduk Miskin (\%) & 14,15 & 13,33 & 12,49 \\
5. & Pertumbuhan Ekonomi (\%) & 4,6 & 6,1 & 6,5 \\
6. & PDB (ADHK 2000) Menurut Lapangan Usaha (Rp. Miliar) & $2.178 .850,4$ & $2.313 .838,0$ & $2.463 .242,0$ \\
\hline
\end{tabular}

Sumber: Berbagai Sumber. Badan Pusat Statistik (BPS). Data Diolah. 2012. 
Tabel 2. Versi Pembagian Subsektor Industri Kreatif Menurut Negara

\begin{tabular}{|c|c|c|}
\hline \multicolumn{3}{|c|}{ SUBSEKTOR INDUSTRI KREATIF } \\
\hline $\begin{array}{l}\text { The Government's Department } \\
\text { for Culture, Media and Sport } \\
\text { (DCMS) of The United Kingdom } \\
\text { (13 Kategori - 2001) }\end{array}$ & $\begin{array}{l}\text { Framework for Cultural Statistic } \\
\text { (FCS) UNESCO } \\
\text { (10 Kategori - 1986) }\end{array}$ & $\begin{array}{l}\text { Klasifikasi Baku Lapangan } \\
\text { Usaha Indonesia (KBLI) } \\
\text { (14 Kategori - 2006) }\end{array}$ \\
\hline Periklanan; & Peninggalan Budaya; & Periklanan; \\
\hline Arsitektur; & Penerbitan \& Percetakan; & Arsitektur; \\
\hline Pasar Seni \& Barang Antik; & 2 \& 3. Musik \& Seni Pertunjukan; & Pasar Seni \& Barang Antik; \\
\hline Kerajinan; & 4. Gambar Seni; & Kerajinan; \\
\hline Desain; & 5 \& 6. Media Audiovisual & Desain; \\
\hline Desainer Fesyen; & Sinema \& Fotografi; \& 6 & Fashion (Mode); \\
\hline Film \& Video; & Radio \& Televisi) & Film, Video, \& Fotografi; \\
\hline Piranti Lunak Permainan & Aktivitas Sosio-Kultural; & Permainan Interaktif; \\
\hline Interaktif; & Olah Raga \& Permainan & 9. Musik; \\
\hline Musik; & Interaktif; & 10. Seni Pertunjukan; \\
\hline Seni Pertunjukan; & Lingkungan \& Alam. & 11. Penerbitan \& Percetakan; \\
\hline Penerbitan; & & 12. Layanan Komputer \& Piranti \\
\hline Piranti Lunak \& Layanan & & Lunak; \\
\hline Komputer; & & 13. Radio \& Televisi; \\
\hline 13. Televisi \& Radio. & & 14. Penelitian dan Pengembangan. \\
\hline
\end{tabular}

Sumber: DCMS (2001), FCS UNESCO (1986), dan KBLI (BPS; 2006).

pembenahan terhadap infrastruktur dan faktor-faktor pendukung pertumbuhan ekonomi kreatif. Dalam perspektif manajemen, diperlukan langkah strategis berupa pembinaan, perumusan regulasi/kebijakan yang lebih implementatif, pengalokasian anggaran dalam APBN maupun APBD, penguatan kapasitas usaha dan pola pendampingannya, monitoring dan evaluasi disertai pembangunan sistem dan basis datanya. Pembenahan ini akan mendukung penciptaan iklim ekonomi kreatif yang telah dimotori oleh masyarakat, sehingga menjadi lebih kondusif dan produktif.

Apa dan bagaimana konsep ekonomi kreatif itu? Ekonomi kreatif digagas pertama kali di Inggris oleh John Howkins (2001) melalui bukunya "Creative Economy, How People Make Money from Ideas". Ide Howkins diinspirasi oleh pemikiran Robert Lucas yang melihat bahwa pertumbuhan ekonomi suatu wilayah sangat ditentukan oleh tingkat produktivitas dan keberadaan orang-orang kreatif yang memiliki talenta khusus dengan kemampuan mengaplikasikan ilmu pengetahuan untuk menciptakan suatu inovasi. Menurut Howkins, "Ekonomi Kreatif" merupakan aktivitas perekonomian yang lebih mengandalkan ide atau gagasan (kreatif) untuk mengelola material yang bersumber dari lingkungan di sekitarnya menjadi bernilai tambah ekonomi. Selanjutnya, konsep ekonomi kreatif tersebut dikembangkan oleh Florida melalui kedua karyanya, yakni: "The Rise of Creative Class" dan "Cities and the Creative Class".

Lantas, apakah "Kreatif" itu? Menurut Webster's New World Dictionary (1991; 325), kreatif merupakan kata sifat yang berasal dari Bahasa Latin creativus yang mengandung pengertian 1 creating or able to create 2 having or showin imagination and artistic or intelectual inventiveness [creative writing] 3 stimulating the imagination and inventive power [creative toys] 4 imaginatively or invetively deceptive [creative accounting]. Dalam Kamus Besar Bahasa Indonesia (2005: 599) pengertian kreatif adalah: 1 memiliki daya cipta; memiliki kemampuan untuk menciptakan; 2 bersifat (mengandung) daya cipta. Kreativitas berarti: 1 kemampuan untuk mencipta; daya cipta; dan 2 perihal berkreasi; kekreatifan (perihal kreatif).

Pendapat lain menyatakan kata "kreativitas" berasal dari bahasa Latin "creatus" yang akar katanya adalah "creare", artinya "membuat, meneruskan, menghasilkan, memperanakkan, membiakkan," dan berkaitan maknanya dengan "crescere" yang berarti "bangkit, tumbuh". Jadi, terdapat padanan kata kreatif, yaitu "membuat" atau "mencipta", dan kata bentukan "creative" dan "creativity" menjadi "kreatif" (kata sifat) dan "kreativitas" (kata benda). "Karya" adalah wujud dari kreativitas, sedangkan "Kerja" merupakan jalan mewujudkan kreativitas. http://sejutapuisi.blogspot.com/2011/12/kolom-berimajinasilahjadilah-kreatif.html).

United Nations Conference on Trade and Development (UNCTAD) dalam "Creative Economy Report 2010" (2010; 10) mendefinisikan ekonomi kreatif sebagai "The "creative economy" is an evolving concept based on creative assets potentially generating economic growth and development. - It can foster income generation, job creation and export earnings while promoting social inclusion, cultural diversity and human development. - It embraces economic, cultural and social aspects interacting with technology, intellectual property and tourism objectives. - It is a set of knowledge- 
Tabel 3. Peta Industri Kreatif dalam Perekonomian Indonesia Tahun 2010

\begin{tabular}{|c|c|c|}
\hline Jumlah Penduduk & & 237.641.326 Jiwa \\
\hline Kontribusi Terhadap PDB & & $7,2 \%$ \\
\hline Kontribusi Terhadap Ekspor & & $9 \%$ \\
\hline Penyerapan Tenaga Kerja & & $\pm 7,5$ Juta Pekerja \\
\hline Lingkup Kegiatan Utama & $\begin{array}{ll}\text { 1. } & \text { Fashion } \\
\text { 2. } & \text { Kerajinan } \\
\text { 3. } & \text { Periklanan } \\
\text { 4. } & \text { Desain } \\
\text { 5. } & \text { Arsitektur }\end{array}$ & $\begin{array}{ll}\text { 6. } & \text { Penyiaran } \\
\text { 7. } & \text { Penerbitan } \\
\text { 8. } & \text { Musik } \\
\text { 9. } & \text { Pengembangan Perangkat Lunak }\end{array}$ \\
\hline Peraturan Perundang-undangan & $\begin{array}{ll}\text { - } & \text { Instruksi Pre } \\
\text { - } & \text { Ckonomi Kre } \\
\text { - } & \text { etak Biru E } \\
\end{array}$ & $\begin{array}{l}\text { r } 6 \text { Tahun } 2009 \text { Tentang Pengembangan } \\
\text { eatif Indonesia Tahun 2009-2025 }\end{array}$ \\
\hline
\end{tabular}

Sumber: Statistik Indonesia dan Global Business Guide Indonesia 2011. Data Diolah. 2012.

based economic activities with a development dimension and cross-cutting linkages at macro and micro levels to the overall economy. - It is a feasible development option calling for innovative, multidisciplinary policy responses and interministerial action. - At the heart of the creative economy are the creative industries."

Menyimak berbagai konsep dan pengertian tersebut, secara realistis-sederhana ekonomi kreatif (creative economy) diartikan sebagai talenta (ide kreatif-inovatif) dengan nilai ekonomi yang mampu merubah kualitas hidup manusia menjadi lebih sejahtera. Ekonomi kreatif lebih mengandalkan kreativitas individu melalui gagasan, daya kreasi, dan daya cipta untuk meningkatkan nilai tambah ekonomi karyanya, sehingga mampu menciptakan lapangan kerja dan kesejahteraan.

Merespon transformasi perekonomian tersebut, Pemerintah Indonesia secara resmi meluncurkan Program Ekonomi Kreatif (Instruksi Presiden Nomor 6 Tahun 2009 Tentang Pengembangan Ekonomi Kreatif) yang wajib dilaksanakan oleh beberapa kementerian/lembaga dan seluruh pemerintahan daerah (provinsi dan kabupaten/ kota). Presiden juga mencanangkan Tahun 2009 sebagai Tahun Indonesia Kreatif. Namun, memerhatikan berbagai keterbatasan, Pemerintah menetapkan prioritas pengembangan ekonomi kreatif dalam kurun waktu 2009 - 2014 difokuskan kepada 7 (tujuh) kelompok industri kreatif, yaitu: (1) arsitektur; (2) fesyen; (3) kerajinan; (4) layanan komputer dan piranti lunak; (5) periklanan; (6) permainan interaktif; dan (7) riset dan pengembangan.

Kini, manfaat ekonomi kreatif semakin dirasakan. Peta Industri Kreatif Dalam Perekonomian Indonesia Tahun 1020 (Data Global Business Guide Indonesia - 2011) menunjukkan andil industri kreatif dalam perekonomian dalam negeri. (http://www.gbgindonesia.com/en/services/ article/2011/indonesia_s_creative_industries.php)

$$
\text { Menyimak besarnya penyerapan }
$$

sumberdaya manusia (SDM) yang mencapai $\pm 7,5$ juta pekerja di subsektor industri kreatif, menandakan besarnya potensi anak negeri bertalenta kreatif. Latuconsina (2010: 20) menyatakan bahwa sumberdaya manusia (SDM) kreatif adalah syarat untuk mengisi peranan dalam industri kreatif. Industri kreatif adalah jalan untuk membangun ekonomi kreatif atau ekonomi berbasis pengetahuan (knowledge based economy). Dan ekonomi model ini adalah fondasi ekonomi yang dibangun berdasarkan sinergisitas antara talenta SDM dan keunggulan alam, yang ditandai dengan pertumbuhan cepat, penambahan nilai yang tinggi, serta perspektif sosial yang positif.

Apa makna yang dapat kita peroleh, terutama di era otonomi daerah? Keberadaan dan keberlanjutan pemerintahan daerah menuntut penyelenggaraan pemerintahan daerah yang bersifat efisien, efektif, ekonomis, dan produktif. Artinya, diperlukan sinergisitas dan kohesitas antara pemerintahan daerah dan masyarakatnya untuk bersama-sama mengeksplorasi potensi, kekayaan budaya, dan kearifan lokal sesuai karakteristik wilayahnya dalam koridor peraturan perundangundangan, sehingga terjadi percepatan pembangunan dan pertumbuhan ekonomi daerah yang signifikan menuju terwujud masyarakat sejahtera. Kepedulian Pemerintah dan pemerintahan daerah menjadi penentu berkembangnya industri kreatif. Anggraini (2008: 150-151) mengungkapkan 6 (enam) argumentasi perlunya pengembangan industri kreatif di Indonesia, yakni:

1. Dari sisi "Kontribusi Ekonomi", menciptakan lapangan kerja, meningkatkan produk domestik bruto (PDB), dan ekspor;

2. Dari sisi "Iklim Bisnis", menciptakan lapangan usaha, dampak bagi sektor lain, dan pemasaran;

3. Dari sisi "Citra dan Identitas Bangsa", meningkatkan turisme, ikon nasional, membangun budaya, warisan budaya, dan nilai lokal;

4. Dari sisi "Sumberdaya Terbarukan", berbasis pengetahuan, kreativitas, dan membangun komunitas hijau;

5. Dari sisi "Inovasi dan Kreativitas", memberikan ide, gagasan, dan penciptaan nilai; dan 
6. Dari sisi "Dampak Sosial", meningkatkan kualitas hidup, pemerataan kesejahteraan, dan peningkatan toleransi sosial.

Dalam perkembangannya akan memberikan kontribusi ekonomi yang signifikan, menciptakan iklim bisnis yang positif, membangun citra dan identitas bangsa. Selain itu, sumberdaya dapat selalu terbarukan yang berbasis pengetahuan, kreativitas dan komunitas hijau, menuju keunggulan kompetitif bangsa berdampak sosial positif.

Dalam konteks yang lebih luas, daerah (terutama perkotaan) harus mampu menjadi wahana bagi masyarakatnya untuk membentuk pola pikir, pola tindak, pola sikap, pola berusaha, dan pola hidup yang terencana dengan daya imajinasi yang berbasis kekayaan alam, budaya, dan keunggulan daerah. Perkotaan harus mampu menjadi 2L (locus dan locomotive) perubahan yang dapat memerankan dirinya sebagai regulator sekaligus katalisator dengan memberikan kebebasan kepada semua orang agar meningkatkan kapasitas individu, mengembangkan diri secara profesional, dan berkembang sesuai dinamika pembangunan yang berkelanjutan.

Merespons ide kreatif dan upaya menghadirkan kota kreatif, United Nations Educational, Scientific, and Cultural Organization atau Organisasi Pendidikan, Ilmu Pengetahuan, dan Kebudayaan Perserikatan Bangsa-Bangsa (UNESCO) membentuk Jaringan Kota-kota Kreatif (JKK/The Creative Cities Network) pada tahun 2004. JKK bertujuan mempromosikan dan mempertahankan keberagaman budaya melalui pertukaran pengalaman dan merumuskan strategi untuk menghadapi arus globalisasi. Kota-kota kreatif tersebut merupakan bagian dari sistem pemerintahan daerah yang terdiri atas berbagai komunitas mitra (pemerintah/swasta), organisasi profesi, masyarakat sipil, lembaga budaya, dan lain-lain.

Saat ini, UNESCO sudah menetapkan 30 (tiga puluh) kota yang terdapat di 19 (sembilan belas) negara sebagai "Kota Kreatif". Seluruh kota tersebut tergabung dalam keanggotaan JKK menurut 7 (tujuh) kategorisasi lapangan industri kreatif sebagaimana disajikan pada Tabel 4

Ketentuan Creative Cities Network (CCN) UNESCO mewajibkan setiap anggotanya tergabung dalam jaringan kota-kota kreatif dengan durasi tak terbatas dan dapat meninggalkannya setiap saat dengan ketentuan terlebih dahulu memberitahukan kepada UNESCO. Dalam perspektif hak, kota yang ditunjuk dan ditetapkan sebagai "Kota Kreatif" berhak menggunakan nama dan logo UNESCO

Tabel 4. Daftar Jaringan Kota-kota Kreatif Menurut Negara Asal dan Lapangan Industri Kreatif Tahun 2011

\begin{tabular}{|c|c|c|c|c|}
\hline Jenis Industri Kreatif & & Negara Asal & & Nama Kota \\
\hline \multirow[t]{5}{*}{ Sastra (Literature) } & 1. & Inggris & 1. & Edinburgh \\
\hline & 2. & Australia & 2. & Melbourne \\
\hline & 3. & Amerika Serikat & 3. & Iowa City \\
\hline & 4. & Irlandia & 4. & Dublin \\
\hline & 5. & Islandia & 5. & Reykjavik \\
\hline \multirow[t]{2}{*}{ Tontonan (Film) } & 1. & Inggris & 1. & Bradford \\
\hline & 2. & Australia & 2. & Sydney \\
\hline \multirow[t]{5}{*}{ Musik (Music) } & 1. & Spanyol & 1. & Seville \\
\hline & 2. & Italia & 2. & Bologna \\
\hline & 3. & Inggris & 3. & Glasgow \\
\hline & 4. & Belgia & 4. & Ghent \\
\hline & 5. & Kolombia & 5. & Bogota \\
\hline Seni Kerajinan dan & 1. & Amerika Serikat & 1. & Santa Fe \\
\hline Kesenian Rakyat & 2. & Mesir & 2. & Aswan \\
\hline \multirow[t]{2}{*}{ (Crafts and Folk Art) } & 3. & Jepang & 3. & Kanazawa \\
\hline & 4. & Korea Selatan & 4. & Icheon \\
\hline \multirow[t]{10}{*}{ Desain (Design) } & 1. & Argentina & 1. & Buenos Aires \\
\hline & 2. & Jerman & 2. & Berlin \\
\hline & 3. & Kanada & 3. & Montreal \\
\hline & 4. & Jepang & 4. & Nagoya \\
\hline & 5. & Jepang & 5. & Kobe \\
\hline & 6. & China & 6. & Shenzen \\
\hline & 7. & China & 7. & Shanghai \\
\hline & 8. & Korea Selatan & 8. & Seoul \\
\hline & 9. & Perancis & 9. & Saint-Etienne \\
\hline & 10. & Austria & 10. & Graz \\
\hline Seni Media (Media Arts) & 1. & Perancis & 1. & Lyon \\
\hline \multirow{3}{*}{$\begin{array}{l}\text { Tradisional Kulinari } \\
\text { (Gastronomy) }\end{array}$} & 1. & Kolombia & 1. & Popayan \\
\hline & 2. & China & 2. & Chengdu \\
\hline & 3. & Swedia & 3. & Ostersund \\
\hline
\end{tabular}

Sumber: UNESCO. Data Diolah. 2012. 
berdasarkan ketentuan dan persyaratan dalam kontrak grafis UNESCO. Dari sisi kewajiban, setiap tahun "Kota Kreatif" wajib melaporkan kepada UNESCO perihal perkembangan dalam hal kebijakan dan kegiatan, baik lokal maupun internasional dan melakukan kerja sama dengan kota lainnya.

Kota kreatif berarti kota dimana pemerintah maupun masyarakatnya memiliki ide-ide kreatif serta didukung oleh kebijakan publik yang aspiratif untuk pengembangan potensi dan daya saing daerah. Maknanya adalah bagaimana daerah menjadi tempat yang inspiratif, sehingga masyarakat memiliki semangat, kecerdasan, imajinasi, dan kreativitas untuk mengembangkan ekonomi daerahnya. Implikasinya, setiap pemerintahan daerah harus mengeksplorasi kreativitas agar mampu mengelola, menumbuhkembangkan, dan meningkatkan daya saing daerahnya. Siklus inilah yang menentukan eksistensi dan menjamin terselenggaranya pemerintahan daerah secara berkesinambungan. Intinya, kemajuan dan keberhasilan daerah otonom ditentukan oleh keberadaan kelas kreatif dan daya inovasinya. Semakin banyak kelas kreatif dan inovasi di suatu daerah, semakin mempercepat terjadinya perubahan politik, sosial, ekonomi, dan budaya yang mengarah pada kesejahteraan.

Ekonomi kreatif dalam perspektif penyelenggaraan pemerintahan daerah idealnya dibangun dari ide-ide inovatif (innovation) yang mampu menstimulasi pertumbuhan ekonomi, bisnis, dan investasi (growing business), berorientasi daya saing menuju transformasi industri kreatif (competition), dan dapat meningkatkan kesejahteraan masyarakat (people welfare). Dalam konteks ini, pra kondisi diperlukan untuk: (1) identifikasi dan inventarisasi jenis dari 14 subsektor ekonomi kreatif di daerah; (2) membangun database; (3) merumuskan kebijakan, orientasi, target capaian, dan strategi pengembangan; (4) peningkatan kapasitas kelembagaan pengelola ekonomi kreatif di daerah; (5) menata prosedur, mekanisme, dan jaringan untuk pemasaran produk ke pasar domestik maupun mancanegara; (6) meningkatkan kompetensi sumberdaya manusia (SDM); (7) menjamin kualitas produk dan pelayanan pasca jual; dan (8) kelestarian lingkungan demi keberlangsungan usaha.

Persoalannya justru sejauhmana kreativitas pemerintah, pemerintah daerah, dan masyarakat saat ini? Kreativitas merupakan talenta yang mampu membuahkan potensi besar dan mendukung keberlanjutan perekonomian individu, masyarakat, daerah, dan bahkan nasional. Namun, sejauhmana "kreativitas" (ekonomi kreatif dan industri kreatif) mampu memicu daya saing daerah dan daya saing nasional?

\section{METODE PENELITIAN}

Studi ini bertujuan untuk lebih memahami keberadaan ekonomi kreatif sebagai talenta baru yang diprediksi mampu memicu daya saing daerah. Dalam upaya mengeksplorasi isu-isu ekonomi kreatif digunakan metode deskriptif dengan analisis data secara kualitatif. Analisa kualitatif difokuskan pada pemaknaan manajemen untuk mendapatkan deskripsi kinerja terbaik (best performance) serta upaya-upaya terbaik (best effort) yang telah ditempuh oleh pemerintah dan terutama oleh pemerintahan daerah dalam rangka keterpaduan dan sinergisitas pelaksanaan pengembangan ekonomi kreatif. Dengan demikian dapat diketahui kondisi senyatanya berupa dinamika dan problematika dalam upaya pengembangan ekonomi kreatif di tanah air.

Penelusuran literatur (literature study) menjadi sarana utama untuk memperoleh informasi dan data sekunder. Kebutuhan data sekunder diperoleh dari Badan Pusat Statistik (BPS). Beberapa literatur dan/atau dokumen yang digunakan antara lain: peraturan perundang-undangan, hasil penelitian, dan referensi berupa jurnal, buku teks, kamus, dokumen, internet serta berbagai artikel yang terkait dengan ekonomi kreatif. Selanjutnya, data disajikan dalam bentuk tabel. Beberapa data yang diperoleh dari kementerian/lembaga pemerintah non kementerian (K/LPNK) sudah diolah dan merupakan hasil penelitian terdahulu.

\section{HASIL DAN PEMBAHASAN}

Sebagai talenta baru, ekonomi kreatif diharapkan mampu menjadi pengungkit daya saing (daerah maupun nasional). Eksistensinya memerlukan pengakuan yang harus diwujudkan melalui berbagai regulasi/kebijakan dan kebersamaan tindakan antara regulator, mediator, fasilitator, implementor, aktor, dan bahkan penerima manfaat lainnya (beneficiaries).

Secara manajerial, dalam perspektif sense of urgency, diidentifikasi 5 (lima) agenda pengembangan ekonomi kreatif yang memerlukan penataan dan pengelolaan secara paripurna. Kelima agenda tersebut, yaitu: (1) pemetaan kendala operasional; (2) upaya terobosan; (3) komitmen dan tindakan; (4) kesadaran masyarakat; dan (5) pentingnya basis data.

\section{Pemetaan Kendala Operasional}

Semenjak pencanangan Tahun Ekonomi Kreatif pada tahun 2009, kondisi ekonomi kreatif Indonesia senantiasa mengalami perkembangan. Perkembangan teknologi informasi, lapangan usaha jasa, dan meningkatnya angkatan muda berpendidikan (skill) memberikan kontribusi yang signifikan bagi pertumbuhan ekonomi kreatif. Berdasarkan Hasil Riset dan Pemetaan Industri Kreatif Kementerian Perdagangan 2011, diperoleh 
Tabel 5. Beberapa Kendala Dalam Aplikasi Ekonomi Kreatif dan Industri Kreatif

\begin{tabular}{|c|c|}
\hline ATOM & $\begin{array}{c}\text { Kendala Pada Lingkup Kegiatan Utama } \\
\text { Industri Ekonomi Kreatif Dalam Perspektif } \\
\text { Administratif, Teknis, Operasional, dan Manajerial (ATOM) }\end{array}$ \\
\hline 1. Administratif & $\begin{array}{l}\text { 1. Prosedur Administrasi; } \\
\text { 2. Regulasi (Administrasi) Ekspor dan Impor; } \\
\text { 3. Biaya Administrasi Perijinan, Pengurusan HKI, \& Pendirian Usaha Relatif Mahal; } \\
\text { 4. Lambannya Proses Pengurusan (Prosedur) Administrasi Ekspor dan Impor; dan } \\
\text { 5. Regulasi Bahan Baku, Khususnya Subsektor Industri Kreatif yang Mengandalkan } \\
\text { Sumber Daya Alam (al. Penerbitan, Percetakan, Fesyen, dan Kerajinan); }\end{array}$ \\
\hline 2. Teknis & $\begin{array}{l}\text { 1. Proteksi terhadap Produk Impor (Substitusi Impor), Kemudahan Impor, dan Larngakan } \\
\text { Ekspor Bahan Baku; } \\
\text { 2. Maraknya Pembajakan Hasil Produksi; } \\
\text { 3. Relatif Rendahya Pemahaman Para Pelaku Ekonomi Kreatif Terhadap Hak Cipta, } \\
\text { Desain, Paten, dan Merk, sehingga Terjadi Pembajakan Produk; } \\
\text { 4. Tingginya Risiko (High Risk) Akibat Kegagalan Produk/Jasa yang Ditawarkan ke Pasar } \\
\text { Domestik maupun Internasional; dan } \\
\text { 5. Belum Tersedianya Regulasi Terkait Insentif Pajak (Tax Holiday) Terutama untuk } \\
\text { Subsektor-subsektor yang Belum Menghasilkan Keuntungan Besar. }\end{array}$ \\
\hline Operasional & $\begin{array}{l}\text { 1. Maraknya impor ilegal; } \\
\text { 2. Penyelundupan yang Mengakibatkan Langkanya Bahan Baku; } \\
\text { 3. Kelangkaan dan Mahalnya Bahan Baku Industri; } \\
\text { 4. Keterbatasan Kanal (Frekuensi) Teknologi Transmisi Penyiaran - Pada Umumnya } \\
\text { Masih Menggunakan Teknologi Analog; dan } \\
\text { 5. Terjadinya Perebutan Kanal karena Pesatnya Pertumbuhan Jumlah Perusahaan } \\
\text { Penyiaran. }\end{array}$ \\
\hline 4. Manajerial & $\begin{array}{l}\text { 1. Keterbatasan SDM Terampil yang Mau Menekuni Industri Kreatif; } \\
\text { 2. Persaingan Usaha, Khususnya di Industri Televisi dan Radio, Periklanan dan Industri } \\
\text { Film, Video, dan Fotografi; } \\
\text { 3. Tenaga Kerja, Khususnya pada Sektor yang Bersifat Padat Karya (Labour Intensif, } \\
\text { seperti: Fesyen, Percetakan Besar, Televisi, dan Beberapa Perusahaan Kerajinan; } \\
\text { 4. Belum Dicapainya Konsensus Antara Pengusaha, Pemerintah, dan Serikat Pekerja } \\
\text { Dalam Penyempurnaan Aturan Tenaga Kerja yang Berusaha Melindungi Tenaga Kerja } \\
\text { dengan Lebih Baik (Karena Labour Market Felxible yang Merupakan Preferensi } \\
\text { Pengusaha Menjadi Terkekang); } \\
\text { 5. Pungutan-pungutan Liar yang Mengurangi Efisiensi dan Mengurangi Akurasi Estimasi } \\
\text { Perhitungan Keuangan, sehingga Menyebabkan Ekonomi Biaya Tinggi; } \\
\text { 6. Belum Semua Perbankan/Lembaga Keuangan Bersedia Membiayai Usaha Ekonomi } \\
\text { Kreatif; dan } \\
\text { 7. Masih Diperlukan Keikutsertaan Perguruan Tinggi Dalam Pembimbingan dan } \\
\text { Penerapan Metode/Teknologi Tepat Guna dan Murah. }\end{array}$ \\
\hline
\end{tabular}

Sumber: KADIN dan Berbagai Sumber. Data Diolah. 2012.

data multiplier effect ekonomi kreatif. Pada tahun 2010, kontribusi output dari ekonomi kreatif mencapai $7,73 \%$, kontribusi tenaga kerja $7,76 \%$, kontribusi jumlah usaha $6,46 \%$, dan kontribusi net trade $33,14 \%$.

Sejauhmana optimasi kontribusi ekonomi kreatif dan kecepatan pencapaiannya terhadap perekonomian dalam negeri masih memerlukan studi tersendiri. Namun, seiring dengan pertumbuhannya, patut pula mencermati kendala operasional yang kerapkali menghambat laju pengembangan ekonomi kreatif di tanah air. Pada tahap awal, Pemerintah bersama-sama masyarakat memerlukan pemahaman bahwa tidak semua potensi kreatif dapat langsung memberikan nilai tambah ekonomi (memiliki nilai jual). Dalam prakteknya, publik seringkali dihadapkan pada beragam kendala ketika hendak memulai usaha di bidang ekonomi kreatif. Kesamaan visi Pemerintah, masyarakat, dunia usaha, dan berbagai organisasi kreatif diharapkan mampu mereduksi sejumlah kendala tersebut.

Bertolak dari beberapa studi, terdapat beberapa persoalan yang secara realistis justru menghambat perkembangan ekonomi kreatif dan industri kreatif di tanah air sebagaimana disajikan pada Tabel 5 .

Mencermati kendala tersebut, ekonomi kreatif di Indonesia belum sepenuhnya didukung regulasi/kebijkan yang memadai, sehingga kondisinya relatif jauh dari kondusif. Implikasinya, 
Tabel 6. Pertumbuhan Industri Kreatif Bidang Penerbitan, Percetakan, dan Reproduksi Media Rekaman (KBLI No. 22) Menurut Jumlah Perusahaan, Tenaga Kerja, dan Pengeluaran untuk Tenaga Kerja Berdasarkan Provinsi Selama Kurun Waktu 5 Tahun (2004-2008)

\begin{tabular}{|c|c|c|c|c|c|}
\hline \multirow[b]{2}{*}{ No. } & \multirow[b]{2}{*}{ Provinsi } & \multicolumn{3}{|c|}{ Pertumbuhan Industri Kreatif } & \multirow[b]{2}{*}{ Keterangan } \\
\hline & & $\begin{array}{c}\text { Jumlah } \\
\text { Perusahaan } \\
(\%)\end{array}$ & $\begin{array}{c}\text { Jumlah } \\
\text { Tenaga } \\
\text { Kerja } \\
(\%) \\
\end{array}$ & $\begin{array}{c}\text { Pengeluaran } \\
\text { Tenaga } \\
\text { Kerja } \\
(\%) \\
\end{array}$ & \\
\hline 1. & Aceh & - & - & - & Tidak Terpetakan (No Data) \\
\hline 2. & Sumatera Utara & - & - & - & Tidak Terpetakan (No Data) \\
\hline 3. & Sumatera Barat & 0 & 2,94 & 20,80 & \\
\hline 4. & Riau & 16,72 & 12,46 & 20,52 & \\
\hline 5. & Kepulauan Riau & - & - & - & Tidak Terpetakan (No Data) \\
\hline 6. & Jambi & 0 & 5,10 & 0,47 & \\
\hline 7. & Sumatera Selatan & 0 & - & - & Data Tidak Lengkap \\
\hline 8. & Kep. Bangka Belitung & - & - & - & Tidak Terpetakan (No Data) \\
\hline 9. & Bengkulu & - & - & - & Tidak Terpetakan (No Data) \\
\hline 10. & Lampung & - & - & - & Tidak Terpetakan (No Data) \\
\hline & SUMATERA & & & & \\
\hline 11. & DKI Jakarta & 1,14 & $(1,13)$ & 330,04 & \\
\hline 12. & Jawa Barat & 7,74 & 8,23 & 31,00 & \\
\hline 13. & Banten & 30,66 & 4,21 & - & \\
\hline 14. & Jawa Tengah & 9,77 & $(2,23)$ & 4,19 & \\
\hline 15. & DI Yogyakarta & 3,13 & 3,29 & 17,26 & \\
\hline 16. & $\begin{array}{l}\text { Jawa Timur } \\
\text { JAWA }\end{array}$ & 8,59 & 6,27 & 17,30 & \\
\hline 17. & Bali & 13,10 & 2,33 & 16,05 & \\
\hline 18. & Nusa Tenggara Barat & - & - & - & Tidak Terpetakan (No Data) \\
\hline 19. & $\begin{array}{l}\text { Nusa Tenggara Timur } \\
\text { BALI - NUSA } \\
\text { TENGGARA }\end{array}$ & - & - & - & Tidak Terpetakan (No Data) \\
\hline 20. & Kalimantan Barat & 10,76 & 24,68 & 44,81 & \\
\hline 21. & Kalimantan Tengah & - & - & - & Tidak Terpetakan (No Data) \\
\hline 22. & Kalimantan Selatan & - & - & - & Tidak Terpetakan (No Data) \\
\hline 23. & $\begin{array}{l}\text { Kalimantan Timur } \\
\text { KALIMANTAN }\end{array}$ & - & - & - & Tidak Terpetakan (No Data) \\
\hline 24. & Sulawesi Utara & - & - & - & Tidak Terpetakan (No Data) \\
\hline 25. & Gorontalo & - & - & - & Tidak Terpetakan (No Data) \\
\hline 26. & Sulawesi Tengah & - & - & - & Tidak Terpetakan (No Data) \\
\hline 27. & Sulawesi Selatan & 0 & $(46,87)$ & $(45,33)$ & \\
\hline 28. & Sulawesi Barat & - & - & - & Tidak Terpetakan (No Data) \\
\hline 29. & $\begin{array}{l}\text { Sulawesi Tenggara } \\
\text { SULAWESI }\end{array}$ & - & - & - & Tidak Terpetakan (No Data) \\
\hline 30. & Maluku & - & - & - & Tidak Terpetakan (No Data) \\
\hline 31. & Maluku Utara & - & - & - & Tidak Terpetakan (No Data) \\
\hline 32. & Papua & - & - & - & Tidak Terpetakan (No Data) \\
\hline 33. & $\begin{array}{l}\text { Papua Barat } \\
\text { MALUKU \& PAPUA }\end{array}$ & - & - & - & Tidak Terpetakan (No Data) \\
\hline
\end{tabular}

Sumber: Daerah Dalam Angka (Provinsi) Kurun Waktu 2005-2011. Data Diolah. 2012.

berbagai kesulitan seringkali dialami stakeholders ekonomi kreatif. Suka tidak suka dan mau tidak mau, Pemerintah maupun pemerintahan daerah dihadapkan pada pilihan untuk segera mereduksi sejumlah kendala dimaksud melalui terobosan, sehingga dapat menghemat waktu untuk lebih mengoptimalkan pengembangan ekonomi kreatif.

\section{Upaya Terobosan (Breakthrough)}

Menilik kendala yang menghambat pengembangan ekonomi kreatif di Indonesia, Pemerintah maupun pemerintah daerah (pemda) wajib bersinergi untuk mencapai kesepakatan melakukan terobosan sebagai solusi yang bermakna bagi para pelaku ekonomi kreatif. Terobosan merupakan langkah strategis, karena dalam proses pengembangan ekonomi kreatif terutama di daerah merupakan hubungan sistemik dan saling ketergantungan antar kesepuluh aspek utamanya, yakni:

1. Sumberdaya manusia (SDM) yang kreatif dengan pemikiran inovatif;

2. Inovasi dan kreativitas berciri keunggulan lokal yang berdaya saing global;

3. Regulasi/kebijakan yang disertai upaya penegakan hukum (law enforcement); 
4. Insentif bagi pengembangan produk ekonomi kreatif;

5. Pasar dan pola pengaturannya (ekspor-impor);

6. Teknologi dan metode yang ramah lingkungan;

7. Ketersediaan material lokal dan optimalisasi pemanfaatannya;

8. Kepercayaan dunia perbankan, lembaga permodalan, dan dunia usaha;

9. Aksesibilitas dan konektivitas (jejaring); dan

10. Masyarakat yang apresiatif dan mendukung kekayaan intelektual (HKI).

Salah satu terobosan penting adalah melakukan pemetaan terhadap 14 subsektor ekonomi kreatif. Belum semua pemerintah daerah memiliki data/informasi yang setara terkait ekonomi kreatif. Upaya terobosan akan menjadi pembuka bagi kemajuan industri kreatif dan ekonomi kreatif di daerah.

\section{Komitmen dan Tindakan (Commitment and Actions)}

Komitmen dan tindakan menjadi momentum penting bagi kemajuan pertumbuhan ekonomi kreatif. Political will dan political action Pemerintah dan pemerintahan daerah akan memberikan kepastian bagi para pelaku industri dan ekonomi kreatif untuk menentukan sikap dan mengambil keputusan serta menetapkan langkahnya. Setidaknya komitmen dan tindakan diwujudnyatakan melalui perumusan peraturan pemerintah (PP) tentang pengembangan ekonomi kreatif. Namun, bila dirasakan sebagai kebutuhan mendesak, maka diperlukan kemauan untuk segera menetapkan peraturan bersama antara 9 (sembilan) menteri/ kepala lembaga, yakni: (1) Menteri Pariwisata dan Ekonomi Kreatif; (2) Menteri Dalam Negeri; (3) Menteri Luar Negeri; (4) Menteri Perindustrian; (5) Menteri Perdagangan; (6) Menteri Pendidikan; 7) Menteri Negara Riset dan Teknologi; (8) Menteri Negara Perencanaan Pembangunan Nasional/Kepala Bappenas; dan 9) Gubernur Bank Indonesia.

Selanjutnya, Pemerintah bersama-sama dengan pemerintahan daerah provinsi melakukan pembinaan dan fasilitasi antara lain dapat berupa pengembangan kapasitas para pemangku kepentingan (stakeholders) industri dan ekonomi kreatif di kabupaten/kota dalam wilayahnya secara serentak. Kesatuan gerak langkah ini akan menentukan skala pengembangan usaha sesuai kebutuhan pasar domestik dan mancanegara, sehingga dapat diidentifikasi jenis kebutuhan dan kendala yang akan dihadapi ketika masyarakat melakukan usaha ekonomi kreatif.

\section{Kesadaran Masyarakat (People Awareness)}

Banyak diantara kita yang belum mengenal dan memahami industri dan ekonomi kreatif. Pada umumnya, masyarakat hanya mengetahui hasil-hasil kerajinan sebagai karya yang mengekspresikan suatu budaya atau kebudayaan dan dijual. Bagaimana kemanfaatan yang dapat langsung dirasakan, seberapa besar rintangan, dan bagaimana mengapresiasi upaya yang dilakukan oleh pelaku ekonomi kreatif belum menjadi kepedulian kebanyakan orang.

Dilihat dari perspektif geo-ekonomi dan geo-regional yang diintegrasikan dengan kondisi demografisnya, nampak bahwa jumlah dan sebaran penduduk Indonesia merupakan modal utama pengembangan ekonomi kreatif. Penduduk merupakan aset untuk mengapresiasi produk-produk ekonomi kreatif di tanah air. Idealnya, setiap daerah menciptakan ekonomi kreatif berdasarkan spesifikasi dan kekhasan wilayahnya masing-masing. Jika tahapan tersebut telah terwujud, yang harus dilakukan adalah menata aksesibilitas dan konektivitasnya, sehingga dapat terjadi multiplier effect bagi pertumbuhan perekonomian daerah.

Pemerintah wajib menumbuhkan kesadaran masyarakat, sehingga mereka semakin menghargai, mengenali, dan bahkan menggali berbagai potensi modal kreativitas yang dimiliki dan ada di dalam masyarakat itu sendiri. Secara fundamental, Sun (2010) menjelaskan bahwa menjadi kreatif sangatlah penting. Sama pentingnya menjadikan kreativitas sebagai gaya hidup masyarakat, karena kreativitas dapat digunakan untuk mengatasi berbagai masalah.

Dengan kata lain, kesadaran masyarakat yang diwujudkan melalui apresiasi terhadap semua potensi ekonomi kreatif akan meningkatkan transaksi ekonomi kreatif. Selain itu, animo masyarakat dapat ditumbuhkan melalui penciptaan ide kreatif yang mengacu pada karakteristik, keunggulan, dan keunikan masing-masing wilayah. Tingkat konsumsi utamanya belanja rumah tangga, ekspor, dan investasi yang tercipta di setiap daerah akan melahirkan budi serta karya yang merefleksikan kultur ke-Indonesiaan.

\section{Pentingnya Basis Data (Database)}

Basis data menjadi suatu keniscayaan ketika pemerintah hendak mengembangkan ekonomi kreatif. Ketersediaan kebijakan/regulasi dan data/informasi yang akurat akan memudahkan proses evaluasi dalam kerangka mencari terobosan untuk pengembangannya lebih lanjut. Basis data menjadi media komunikasi antarpelaku ekonomi kreatif yang mampu memberikan penjelasan ringkas mengenai berbagai perkembangan dan kendala terkait 14 subsektor Ekonomi Kreatif. Basis data harus diterbitkan oleh dan atas kerjasama Pemerintah dengan pemerintahan daerah.

Sebagai catatan, dalam upaya memenuhi kebutuhan analisis, dilakukan penelusuran data dari keempatbelas subsektor industri kreatif berdasarkan wilayah provinsi. Dokumen yang digunakan adalah Daerah Dalam Angka (33 provinsi) Tahun 2005 sampai dengan Tahun 2011.

Mencermati Tabel 6, diakui sulitnya mencari dan menggali data industri/ekonomi kreatif. 
Penyebabnya, tidak tersedianya basis data. Tidak semua subsektor industri kreatif dapat dipetakan dan tersimpan datanya. Menurut KBLI 2006, hanya industri kreatif penerbitan dan percetakan yang masuk dalam kategori penerbitan, percetakan, dan reproduksi media rekaman (KBLI No. 22) berhasil didata dengan relatif baik dalam beberapa buku Daerah Dalam Angka.

Kondisi ini membuktikan bahwa Pemerintah maupun pemerintahan daerah belum menyentuh dan membangun basis data. Implikasinya, terdapat sejumlah kesulitan dalam proses identifikasi dan inventarisasi ekonomi kreatif di tataran pemerintahan daerah. Padahal, pemerintah daerah memiliki kepentingan untuk menyejahterakan masyarakatnya dan meningkatkan penerimaan daerah. Di sisi lain, pemerintah daerah harus dapat menjadi motor penggerak ekonomi kreatif melalui pembinaan, pengembangan kapasitas dan pendampingan usaha-usaha yang berbasis kreativitas.

Data membuktikan bahwa pertumbuhan jumlah perusahaan dalam kurun waktu 5 (lima) tahun (2004-2008) senantiasa diikuti dengan peningkatan daya serap tenaga kerja dan besarnya pengeluaran untuk pembiayaan pekerja. Artinya, industri kreatif mampu menciptakan lapangan kerja baru (pro job), meningkatkan pendapatan per kapita masyarakat (pro poor), meningkatkan perekonomian daerah (pro growth), dan menumbuhkan iklim bisnis (pro business). Namun, minimnya data statistik ekonomi kreatif berdasarkan 14 subsektor industri kreatif di setiap wilayah provinsi menyebabkan nilai tambah ekonomi sulit dipetakan dan diperhitungkan kontribusinya secara tepat terhadap kemajuan daya saing daerah.

Keterbatasan dan minimnya data ekonomi kreatif mengindikasikan bahwa ekonomi kreatif belum dikelola secara profesional dari hulu ke hilir. Idealnya, secara manajemen, kecepatan pertumbuhan 14 subsektor ekonomi kreatif yang berbasis budaya dan potensi lokal akan semakin memperkokoh identitas ke-Indonesia-an. Hal ini telah direfleksikan melalui ide kreatif dan inovatif putra-putri Indonesia dari seluruh pelosok negeri. Belum semua provinsi mendata dan memiliki data yang komprehensif, namun setidaknya terdapat 11 provinsi yang telah berupaya memonitor pertumbuhan industri kreatif di wilayahnya, walaupun baru pada bidang Penerbitan, Percetakan, dan Reproduksi Media Rekaman.

Disinilah, campur tangan Pemerintah, kepedulian pemerintah daerah, apresiasi masyarakat terutama terhadap kelima pilar utama model pengembangan industri dan ekonomi kreatif, yakni: 1) industry; 2) technology; 3) resources; 4) institution; dan 5) financial intermediary (Mauled, 2010:294-297) akan lebih menstimulasi munculnya talenta-talenta baru di daerah. Selain itu, pengelolaannya secara komprehensif, terintegrasi, dan profesional akan mendorong dan mempercepat pertumbuhan ekonomi kreatif. Agung (2011) lebih menandaskan bahwa ide kreatif dapat segera terwujud kalau kita cukup tangguh untuk mengembangkannya sampai menjadi sempurna. Artinya, upaya pengembangan ekonomi kreatif memerlukan keseriusan, kekerasan hati, dan kegigihan. Hal ini sejatinya merupakan keniscayaan yang harus diapresiasi dan direspon positif oleh setiap pemerintah daerah, sehingga makin mengukuhkan pentingnya industri dan ekonomi kreatif bagi pertumbuhan ekonomi dan peningkatan daya saing daerah, bahkan nasional.

\section{SIMPULAN}

Memerhatikan hasil analisis dan pembahasan diperoleh simpulan sebagai berikut: Pertama, penetapan 14 subsektor industri kreatif belum diiringi upaya penyiapan yang sistemik, khususnya pada tataran regulasi, infrastruktur penunjang, dan basis data. Hanya beberapa pemerintah daerah yang telah melakukan pendataan terhadap industri kreatif yang berkembang di wilayahnya. Artinya, sebagian besar pemerintah daerah belum menyadari keberadaan ekonomi kreatif sebagai suatu talenta baru yang dapat menghasilkan nilai tambah ekonomi dan bahkan memicu daya saing daerah.

Kedua, kehadiran ekonomi kreatif sebagai wujud ide kreatif-inovatif masyarakat dan manfaat keekonomiannya, belum mampu menstimulasi pemerintah daerah untuk segera merespon melalui pengaturan dan penataan serta pengembangan usaha dan produk-produk kreatif yang mampu memberikan nilai tambah ekonomi dan kemanfaatannya dapat langsung dirasakan masyarakat.

Ketiga, diversifikasi budaya dan potensi wilayah yang spesifik dan sangat variatif telah mendorong masyarakat untuk melakukan usahausaha dan menghasilkan produk-produk kreatif. Hanya saja, pemerintah daerah belum melakukan upaya yang lebih membumi untuk mengangkat keunggulan, budaya, dan karakteristik wilayahnya, sehingga dapat menstimulasi lahirnya kewirausahaan lokal yang berkontribusi bagi pertumbuhan perekonomian daerah dan turut memicu daya saing daerah, bahkan nasional.

Berbagai pembenahan dan penataan ekonomi kreatif menjadi kebutuhan yang harus segera dilakukan. Komitmen dan tindakan Pemerintah maupun pemerintahan daerah harus didasari aspirasi dan kebutuhan para pemangku kepentingan ekonomi kreatif. Di sisi lain, apresiasi masyarakat menjadi salah satu faktor penentu keberhasilan peningkatan daya saing daerah melalui ekonomi kreatif. Atas dasar itu, dalam upaya peningkatan daya saing daerah melalui ekonomi kreatif, Pemerintah bersama-sama Pemerintahan Daerah (provinsi maupun kabupaten/kota) segera mengaplikasikan beberapa agenda berikut ini secara 
sinergis, simultan, terintegrasi, dan terkoordinasi. Agenda dimaksud adalah:

1. Mengidentifikasi dan menginventarisasi usahausaha dan jenis produk ekonomi kreatif yang ada dan berkembang di wilayah provinsi dan kabupaten/kota.

2. Mereviu, menata kembali, dan mencabut regulasi/kebijakan yang menghambat peningkatan daya saing daerah melalui produkproduk hasil ekonomi kreatif, khususnya dalam hal penyediaan bahan baku, impor, dan ekspor.

3. Melakukan pengembangan kapasitas (capacity building) khususnya bagi para pemangku kepentingan (stakeholders) ekonomi kreatif dari berbagai jenis komoditas perdagangan yang dihasilkan melalui ide dan pemikiran kreatif.

4. Mendorong dan memfasilitasi pemberian kredit untuk pengembangan usaha di bidang ekonomi kreatif melalui skema pendanaan bergulir yang murah, mudah, dan aman.

5. Mempromosikan dan memfasilitasi pemasaran produk-produk ekonomi kreatif di daerahnya melalui kerjasama daerah dan/atau optimalisasi jaringan usaha di daerah, antara lain melalui Kamar Dagang dan Industri (KADIN).

6. Mendorong para pelaku ekonomi kreatif untuk mendaftarkan produk kreatifnya agar mendapatkan Paten atau Hak Kekayaan Intelektual (HKI), sehingga dapat memberikan nilai tambah.

7. Membangun basis data yang akurat dan terkoneksi antarjenjang pemerintahan serta dapat dimanfaatkan sebagai acuan bagi masyarakat yang memerlukannya.

\section{DAFTAR PUSTAKA}

Agung, Gregorius. 2011. The Explorer, The Warior, and The Saint: The Story About Creativity. Jakarta: PT. Elex Media Komputindo.

Anggraini, Nenny. 2008. Industri Kreatif. Jurnal Ekonomi Desember 2008 Volume XIII, Nomor 3. Diunduh pada hari Jumat, $27 \mathrm{Mei}$ 2012 dari: http://isjd.pdii.lipi.go.id/admin/jurnal/1830814 4151.pdf

Florida, Richard. 2012. The Rise of The Creative Class, Revisited. New York: Basic Books.

Department for Culture, Media, and Sport of the United Kingdom (DCMS UK). 2001. Creative Industries Mapping Document. London. http://www.idea.gov.uk/idk/core/page.do?page $\mathrm{Id}=11136366$.

Latuconsina, Hudaya. 2010. Kreativitas Tanpa Batas Menuju Ekonomi Kreatif Berbasis Insan Kreatif. Cetakan I. Jakarta: TERAJU.

Moelyono, Mauled. 2010. Menggerakkan Ekonomi Kreatif Antara Tuntutan dan Kebutuhan. Edisi I. Cetakan I. Jakarta: Rajawali Pers.

Neufeldt, Victoria dan David B. Guralnik. 1991. Webster's New World Dictionary of American
English. Third College Edition. New York. Prentice Hall.

Tiemann, Thomas., Cassandra DiRienzo, and Jayoti Das. Tolerance, Heterogeneity, Creativity, and Economic Growth. Diunduh hari Jumat, 27 Mei 2012 dari: http://ec.europa.eu/education/ lifelong-learningpolicy/doc/creativity/report/ tolerance.pdf

Tim Redaksi Kamus Besar Bahasa Indonesia Edisi Ketiga, Pusat Bahasa Departemen Pendidikan Nasional. 2005. Kamus Besar Bahasa Indonesia. Edisi Ketiga. Jakarta: Balai Pustaka.

Tim Riset dan Pemetaan Industri Kreatif Kementerian Perdagangan. 2011. Studi Industri Kreatif Di Indonesia. Jakarta: Kementerian Perdagangan.

Sun, Peng Kheng. 2010. The Power of Creativity. Yogyakarta: Penerbit ANDI.

United Nations Educational, Scientific, and Cultural Organization (UNESCO) and Global Alliance for Cultural Diversity (GACD). Understanding Creative Industries Cultural Statistic for Public-Policy Making. Diunduh hari Jumat, 27 Mei 2012. http://portal.unesco.org/culture/es/ files/30297/11942616973cultural_stat_EN.pdf /cultural stat EN.pdf

United Nations. 2010. Creative Economy Report 2010. Creative Economy: A Feasible Development Option. Collaborative Effort Led by United Nations Conference on Trade and Development (UNCTAD) and United Nation Development Programe (UNDP) Special Unit for South-South Cooperation.. Diunduh hari Jumat, 27 Mei 2012 dari: http://www.unctad. org/creative-economy. 
104 | Jurnal Bina Praja | Volume 4 No. 2 Juni 2012: 93 - 104 